\title{
WSPÓLCZESNY DRAMAT UKRAIŃSKI WOBEC WOJNY: NA PRZYKŁADZIE SZTUKI NATALII WOROŻBYT ZLE DROGI
}

\author{
ANDRIEJ MOSKWIN \\ Uniwersytet Warszawski, Warszawa - Polska \\ amoskwin@uw.edu.pl; ORCID: 0000-0003-1699-3556
}

\section{СУЧАСНА УКРАЇНСЬКА ДРАМА ПРОТИ ВІЙНИ: НА ПРИКЛАДІ ДРАМИ НАТАЛІЇ ВОРОЖБИТ ПОГАНІ ДОРОГИ}

\begin{abstract}
АНОТАЦІЯ. Предметом дослідження є драма української авторки Наталії Ворожбит Погані дороги (2017). Письменниця є представником “нової драми” в Україні. Текст був написаний на замовлення театру Royal Court (Лондон). Він також був поставлений у Києві (Scena 6) та отримав нагороду за „Найкращу режисуру” (Тамара Трунова, фестиваль GRA, 2019). Дія драми відбувається під час війни на сході України, у 2014-2016 роках. Письменниця відвідала ці райони і зробила багато інтерв'ю. У Поганих дорогах Н. Ворожбит акцентує увагу не на війні, а на катастрофічному впливі війни на повсякденні сфери життя. Авторка цікавиться, як війна спотворює людський менталітет і психіку, як вона впливає на міжособистісні взаємини в нових умовах, спричиняє бажання нашкодити близьким і невідомим людям та як це відбивається на інтимних стосунках. У цій драмі важливу роль відіграють жінки й такі аспекти, як кохання, секс, еротика та почуття. Автор публікації акцентує увагу на трьох найважливіших проблемах, порушених у тексті: насильство, травма та творення героя (спочатку прославлення, а потім дегероїзація).
\end{abstract}

Ключові слова: Наталія Ворожбит, сучасна українська драматургія, „нова драма”, війна, Україна, героїзація, травма, насильство

\section{CONTEMPORARY UKRAINIAN DRAMA ABOUT THE WAR: NATALIA VOROZHBIT'S PLAY BAD ROADS}

\author{
ANDREY MOSKVIN \\ University of Warsaw, Warsaw - Poland
}


ABSTRACT. The subject of this study is the play Bad roads (2017) written by the Ukrainian playwright Natalya Vorozhbit. The text was commissioned by the Royal Court Theatre (London). It was also staged in Kiev and received the award for "Best Direction" (Tamara Trunova, GRA Festival, 2019). The action in the drama takes place during the war in eastern Ukraine in 2014-2016. The writer visited these areas and conducted many interviews. In Bad roads N. Vorozhbit focuses not on warfare but on the catastrophic impact of war on everyday life. The author is interested in how war damages the human mentality and psyche, how it influences building interpersonal relationships in new conditions, how war produces the desire to hurt people close to us, as well as unfamiliar ones, and how it affects the formation of intimate relationships. It is significant that an important role in the drama was intended for women and aspects such as love, sex and erotic feelings. The author of the publication focuses on the three most important problems raised in the text: violence, trauma and the creation of a hero (first glorification and then de-heroisation).

Keywords: Natalya Vorozhbit, contemporary Ukrainian dramaturgy, "new drama”, war, Ukraine, heroisation, trauma, violence.

$\mathrm{T}$ Trwająca ponad sześć lat (od kwietnia 2014 roku) wojna na Ukrainie jest jednym z najważniejszych konfliktów zbrojnych w Europie po zakończeniu zimnej wojny. Doprowadziła ona do głębokich zranień psychicznych, urazów i depresji. Zadaniem badaczy i naukowców (m.in. socjologów, psychologów) jest naświetlenie tych złożonych zjawisk. Ma to na celu niesienie pomocy ofiarom wojny: uświadomienia im choroby, wskazanie sposobów leczenia i ułatwienie powrotu do zdrowia.

Współczesna literatura ukraińska, w tym dramaturgia, też poświęca tym problemom wiele uwagi. Przykładem może być tu działalność kulturolożki i dramatopisarki Nedy Neżdany ${ }^{1}$. Dzięki jej staraniom ukazały się dwa tomy antologii współczesnego dramatu ukraińskiego, Майдан. До і після (Majdan. Przed i po) [Майдан... 2015: 256] oraz Лабіринт із криги та вогню (Labirynt z lodu i ognia) [Лабіринт... 2019: 432]. Tematyka wojenna zajęła w nich ważne miejsce.

Przedmiotem badań niniejszego tekstu będzie utwór sceniczny innej znanej ukraińskiej dramatopisarki i scenarzystki Natalii Worożbyt Погані дороги (ros. Плохие дороги, Złe drogi, 2017). Pierwsza wersja tekstu dramatu powstała w języku rosyjskim. Nieco później na potrzeby teatru w Ukrainie stworzono także wersję

\footnotetext{
${ }^{1}$ Neda Neżdana (wł. Надія Мірошниченко, ur. 1971, Kramatorsk, obwód doniecki, strona internetowa: http://nejdana.ucoz.ua) — dramatopisarka, poetka, kulturolożka. Mieszka w Kijowie. Ukończyła Kijowski Uniwersytet Lingwistyczny (filologia francuska) i Akademię KijowskoMohylańską (kulturologia). Studiowała w Centrum Współczesnej Dramaturgii Eksperymentalnej Anatolija Diaczenki. Była kierowniczką działu teatralnego pisma „Кіно-Театр” („Kino-Teatr”), pracowała jako kierowniczka literacka, scenarzystka, redaktorka. Założycielka dramaturgicznej biblioteki sztuk na portalu „Вертеп” („Wertep”). Od 2001 r. związana z Narodowym Centrum Sztuki Teatralnej im. Łesia Kurbasa (naukowa współpracowniczka, a od 2007 — kierowniczka działu projektów dramaturgicznych). Wykłada teorię i praktykę dramaturgii na Kijowskim Narodowym Uniwersytecie im. T. Szewczenki. Jedna z założycielek Kijowskiego Niezależnego Teatru „MICT” (,MOST”).
} 
ukraińską. Pierwszy dialog został napisany w 2015 roku na zamówienie jednej z londyńskich galerii, która przygotowywała projekt związany z wykorzystaniem różnych technik dokumentalnych. Wtedy Worożbyt pracowała nad scenariuszem do filmu „Cyborgi” i musiała spędzać dużo czasu na wschodzie Ukrainy. W rezultacie powstała historia kobiety, która zbiera różne materiały i inspiracje do swojej pracy. Obecna na czytaniu dyrektorka teatru Royal Court Elyse Dodgson ${ }^{2}$ zaproponowała jej napisanie pełnego tekstu scenicznego, który teatr miał zamiar wystawić.

„Postanowiłam podjąć to wyzwanie, ale pod warunkiem, że sama wszystko zobaczę. Ponownie jeździłam do tereny objęte operacjami antyterrorystycznymi (ATO), robiłam wywiady. Odwiedzałam jednostki wojskowe, rozmawiałam w żołnierzami. Nie odważyłam się pojechać na donieckiego lotnisko, szczerze mówiąc, nie miałam ochoty zginąć. Ale chyba nawet nikt by mnie tam nie wpuścił. Miałam przewodnika, który dbał o moje bezpieczeństwo. Zarejestrowałam na dyktafonie wiele rozmów, ale po powrocie żadnej nie odsłuchałam. Nigdy tego nie robię. Po prostu zanotowałam na papierze to, co najbardziej utrwaliło mi się w pamięci. Gdy już miałam gotowy tekst, zaczęłam tworzyć historie" [Фанайлова, Ворожбит 2018] — powiedziała pisarka w wywiadzie dla Radia Svoboda. Premiera spektaklu w reżyserii Vicky Featherstone odbyła się 15 listopada 2017 roku. Ukraińska prapremiera miała miejsce na deskach niezależnego centrum teatralnego „Scena 6” (27.09.2018) w reżyserii Tamary Trunowej. Następnie spektakl został włączony do repertuaru Akademickiego Teatru Dramatu i Komedii na Lewym Brzegu (Kijów). W ukraińskim konkursie GRA (2019) przedstawienie otrzymało nagrodę za najlepszą reżyserię.

Natalia Worożbyt (ur. 1975) należy do czołówki współczesnych ukraińskich dramaturgów. Studia dramaturgiczne ukończyła w Instytucie Literackim im. M. Gorkiego (Moskwa, 2000). W latach 1995-2005 mieszkała i pracowała w Moskwie. Po powrocie do Kijowa wraz z niemieckim reżyserem Georgem Genoux założyła Teatr Peresełenca, zajmujący się problemem wojny na wschodzie Ukrainy.

Autorka sztuk: Житие nростых (Żywot prostych, 1994), Девочка со спичками (Dziewczynka z zapałkami, 1995), Ширма (Parawan, 1999), Галка Моталко (Gatka Motatko, 2002), Чего ты хочешь, украинский бог? (Czеgo pragniesz, ukraiński Bogu?, 2004), Демоны (Demony, 2004), Присоединяюсь (Dołaczam się, 2005), Раба хвоста (Niewolnica ogona, 2006), Хроника семьи Хоменко (Kronika rodziny Chomienko, 2006), Реформа брака (Reforma ślubu, 2007), Зернохранилище (Spichlerz, 2008), Дословно на два дня (Dostownie na dwa dni, 2010), Вий. Докудрама (Wij. Dramat dokumentalny, 2011), Mecmo (Miejsce, 2013), Квитка будяк (Kwiat ostu, 2013), Щелкунчик (Dziadek do orzechów,

\footnotetext{
${ }^{2}$ Elyse Dodgson (1945-2018) — dramatopisarka, dyrektorka angielskiego teatru Royal Court. Dzięki niej na londyńską scenę trafiły sztuki młodych dramaturgów z całego świata, np. Wasilija Sigariewa (Rosja), N. Worożbyt (Ukraina).
} 
2013), Дневники Майдана (Dzienniki Majdanu, 2014), Саша, вынеси мусор (Sasza, wynieś śmieci, 2014).

Polska prapremiera sztuki Dzienniki Majdanu (w przekładzie Agnieszki Piotrowskiej) odbyła się w Teatrze Powszechnym w Warszawie (reż. Wojtek Klemm, prem. 24.10.2014). Miesięcznik „Teatr” przez pewien czas zamieszczało felietony literatki. Na język polski zostały przetłumaczone utwory: Wij. Dramat dokumentalny [Nowy dramat... 2015: 55-96] oraz Sasza, wynieś śmieci (obydwa w thumaczeniu Jakuba Adamowicza).

W Zlych drogach N. Worożbyt skupia się nie na działaniach wojennych, lecz na katastrofalnym wpływie wojny na powszednie sfery życia. Autorkę interesuje to, jak wojna zniekształca ludzką mentalność i psychikę, jaki ma wpływ na budowanie relacji międzyludzkich w nowych warunkach, jak wywołuje w człowieku chęć skrzywdzenia bliskich i obcych, w jaki sposób oddziałuje na relacje intymne. Jest znamienne, że ważne role w sztuce zostały przypisane kobietom oraz takim kwestiom, jak: miłość, seks, erotyka, uczucia. Wszystkie te zagadnienia będą przedmiotem moich badań. Jest godne podziwu, że autorce udało się umiejętnie połączyć ze sobą tak istotne i złożone zagadnienia. Dzięki temu sztuka ma wszystkie szanse, aby wejść do kanonu współczesnego dramatu ukraińskiego początku XXI wieku.

Dramat Złe drogi składa się z sześciu różnych epizodów połączonych tematem wojny. Akcja pięciu z nich rozgrywa się podczas wojny, a ostatniego, szóstego, przed jej rozpoczęciem.

Bohaterowie pierwszej historii to dwoje ludzi w średnim wieku: Siergiej trzydziestoośmioletni żołnierz oraz Natasza — czterdziestoletnia dziennikarka. Kobieta otrzymała zadanie zrobienia reportażu o obronie lotniska w Doniecku. Przeprowadziła wywiad z Siergiejem, a podczas drugiego spotkania uświadomiła sobie, że się w nim zakochała. Gdy otrzymuje od Siergieja propozycję wyjazdu na teren tzw. przeprowadzenia operacji antyterrorystycznej (ATO), natychmiast się zgadza. Te kilka dni, które spędza z żołnierzem, są dla bohaterki czymś nadzwyczajnym i wyjątkowym.

Bohaterkami drugiej historii są trzy niepełnoletnie dziewczyny, które mieszkają tuż przy granicy z Republiką Doniecką. Wraz z przybyciem do ich miasteczka ukraińskiej armii nudne życie staje się nieco atrakcyjniejsze. Każda z nich zaprzyjaźniła się z żołnierzem i jest z tego bardzo dumna.

Akcja trzeciej sceny toczy się na punkcie kontrolnym, rozdzielającym dwie miejscowości leżące blisko siebie. Dyrektor szkoły mieszka w ukraińskiej części, a jego miejsce pracy znajduje się po przeciwnej stronie. Musi on codziennie przechodzić kontrolę dwa razy: rano, gdy jedzie do pracy, i wieczorem — gry wraca do domu. Pewnego razu zamiast własnego paszportu przez pomyłkę bierze dokument małżonki. Na szczęście po pewnym czasie odnajduje własny dowód tożsamości i sytuacja kończy się dla niego pomyślnie. 
W czwartym epizodzie jesteśmy świadkami wyprawy żołnierza Władimira i pielęgniarki Ludmiły z okupowanego terytorium do pewnej ukraińskiej miejscowości. Otrzymali oni zadanie przekazania ciała zabitego ukraińskiego oficera jego rodzinie.

Piąta historia przenosi nas do Republiki Donieckiej, gdzie dziennikarka z Kijowa spotyka się z żołnierzem w celu przeprowadzenia rozmowy. Jednak zamiast wywiadu staje się ofiarą agresji i niemalże traci życie.

Ostatnia, szósta scena rozgrywa się niedługo przed rozpoczęciem wojny. Dziennikarka — bohaterka z piątej historii, przez przypadek potrąciła samochodem kurę. W związku z tym udaje się do właścicieli, aby poprosić ich o wybaczenie i pokryć straty. Wasia i jego żona są bardzo zaskoczeni zachowaniem kobiety, jednak dość szybko orientują się, że mogą na tym zyskać. Gdy otrzymują dwieście hrywien, ich apetyt zaczyna rosnąć. Udaje im się wmówić kobiecie, że to nie była zwykła kura, lecz „złota”, która daje wiele jajek: Dziesięć jajek kosztuje trzydzieści hrywien. Jak policzyć, to straciliśmy sto hrywien miesięcznie. A rocznie to będzie 1200 hrywien. Ona mogła się przez dwa lata nieść. A to już 2400 [Worożbyt 2017: 36]. Zaczynają nawet wygrażać: jeśli nie otrzymają tej kwoty, to wezwą milicję albo wsadzą ją do piwnicy i będą czekać, aż nie przyjedzie rodzina z pieniędzmi. Kobieta jest tak wystraszona, że postanawia oddać wszystko, co ma przy sobie: pamiątki od bliskich osób — bransoletkę i łańcuszek. Staruszkowie nie gardzą nawet jej kosmetykami. Gdy ofiara nie ma już nic do przekazania, zostaje wyrzucona z domu.

Ta finałowa scena zajmuje bardzo ważne miejsce w kompozycji dramatu. Jest $\mathrm{w}$ pewnym sensie kluczem do rozszyfrowania zawartego w sztuce przesłania. Mimo że nie dzieje się podczas wojny, jednak dobitnie pokazuje, że agresja we wszystkich możliwych formach i przejawach (zastraszanie, nienawiść, wrogość, przemoc itp.) może mieć miejsce także w zwykłym życiu codziennym. Jesteśmy świadkami tego, że zło może się zrodzić w dowolnym miejscu, pojawić się znikąd. W tej konkretnej sytuacji nawet wtedy, gdy druga osoba wykazuje się życzliwością, chęcią pójścia na kompromis.

Lejtmotywem dramatu są złe drogi. Są one rozbite, niewygodne, nieprzejezdne, trudne do poruszania się. Bohaterowie bez przerwy narzekają na nie. Wyobraź sobie, że taka droga byta tu jeszcze przed wojna. Kiedy uczyłam się w Charkowie, właśnie tędy wracałam na weekend do domu. Plomby z zębów wypadały. A teraz mówia - wojna, wojna. Co ma do tego wojna? [Worożbyt 2017: 18] — mówi Ludmiła do żołnierza.

W tekście dramatu zostają wymienione takie lokalizacje i miejscowości, jak Donbas, lotnisko w Doniecku, Debalcewo, Kirowohrad, Mariupol, Berdiańsk, Popasna, Piski i Szirokine (obwód doniecki), Morze Azowskie, Charków, Równe i Lwów. Akcja trzech z sześciu scen dzieje się w mieście Popasna oraz w jego okolicach. 
Utwór zawiera wiele szczegółów dotyczących działań wojennych i życia codziennego na okupowanym terytorium. Siergiej w rozmowie z Nataszą wspomina o broni masowego rażenia „Buratino”, którą miało zamiar wykorzystać wojsko separatystów. Jest ona bardzo niebezpieczna, ponieważ zabija wszystko, co żyje w promieniu trzech kilometrów. Mężczyzna nie wstydzi się jej opowiedzieć o śmierci trzech żołnierzy, których ciała potem zostały włożone do zamrażarek. Zdarzało się, że podczas obiadu jeden $\mathrm{z}$ oficerów otwierał zamrażarkę, co wywoływało u młodych, dopiero co przybyłych żołnierzy strach i przerażenie.

Siergiej wyznaje jej także, że bał się lekarzy. Gdy podczas operacji usłyszał, jak pielęgniarka powiedziała lekarzowi ,pasuje”, odebrał to jako chęć wycięcia mu jednego z organów. Dlatego zmusił lekarzy, aby zrobili mu zabieg bez narkozy: Znajduje w kieszeni granat, zrywam zawleczkę i wyjmuję. [...] ,,Shyszycie, jeśli ja się wyłącze, to wyłączymy się wszyscy razem". Operują bez narkozy, jeden z medyków mdleje, ale ja nie wypuszczam granatu, i chuj z nimi... Operacja się udała [Worożbyt 2017: 3].

Jedna z uczennic opowiada koleżankom, jak latem 2014 roku wyjechała odpoczywać do Berdiańska. Nie była jednak w stanie tam długo zostać, ponieważ przez cały czas myślała wyłącznie o domu, ojcu i kocie. Gdy wreszcie wróciła, to od razu poszła do centrum miasta: Ide po ulicy i styszę, jak strzelaja... I mnie się tak dobrze zrobiło. Wreszcie jestem w domu! Zatrzymałam się pośrodku ulicy i uśmiecham się, jak głupia [Worożbyt 2017: 8-9]. Z kolei Natasza przytacza epizod związany z pobytem w schronie podczas ataków. Była tam pewna rodzina z trzyletnią dziewczynką, która była bardzo przestraszona. Aby ją uspokoić, rodzicie powiedzieli, że to salwy. Za każdym razem, jak rozlegał się wybuch, ona krzyczała z radości: „Hurrra!”.

Oto pewna starsza kobieta nie jest w stanie pogodzić się z obecnością w mieście ukraińskiej armii. Lubi cofać się w przeszłość i podkreślać, jakie to były dobre czasy. Pewnego razu wyznaje, że życie w mieście przed wojną toczyło się tradycyjnie i spokojnie przez wiele lat. Znaczna część mężczyzna pracowała w kopalni. Kiedy zbliżała się chwila powrotu mężów ze zmiany, to kobiety zbierały się na ławeczce i czekały na nich: Nasze orly z kopalń wracały. Teraz się wszystko zmieniło [Worożbyt 2017: 10].

\section{Bohater wojenny: gloryfikacja i odheroizowanie}

W pierwszej scenie została przytoczona opowieść o oficerze uczestniczącym w obronie donieckiego lotniska. Nagrał on krótkie przemówienie do wrogów i wrzucił na Facebooka. W krótkim czasie otrzymał rekordową liczbę lajków, a kobiety pisały w komentarzach: „bohater” i „chcę urodzić ci dziecko”.

Siergiej z pierwszego epizodu brał udział w obronie lotniska w Doniecku, został ciężko ranny i przeszedł długotrwałą rehabilitację. Dla Nataszy, zresztą tak 
jak i dla wielu ukraińskich kobiet, każdy, kto uczestniczył w tej operacji, jest narodowym bohaterem (,,bohater wojenny, przywódca, patriota” [Worożbyt 2017: 6]). Dziennikarka zaczyna go idealizować, gloryfikować, a nawet ubóstwiać. Po pewnym czasie bohaterka wspomina jedno ze spotkań w następujący sposób: Powiedziałam: ,Jaki pan jest piękny”. Muskut drgną na twej twarzy, zrozumiatam, że zrobiło ci się przyjemnie. Po prostu jesteś bohaterem. Opowiadasz o wojnie, o lotnisku donieckim - obiekcie moich badań. Rysujesz na serwetce nowy i stary terminal, nakreślasz pozycje wroga, wymieniasz nazwy broni. Prawie niczego $z$ tego nie rozumiem, choć udaję, że rozumiem. Jesteś niedostęny i zdystansowany, ale podoba ci się moje zainteresowanie wojna. To jedyna droga do ciebie. Ty rysujesz jedyna drogę z lotniska na tyły. Nazywa się droga życia. Masz potężne ręce [Worożbyt 2017: 1].

Wielkie wrażenie zrobiły na niej kroniki wojenne z udziałem Siergieja. Przekonała się wówczas o jego odwadze i gotowości do zabijania innych (jeśli zajdzie taka potrzeba). Przepełniona radością zadaje pytanie: Dlaczego jest mi tak spokojnie i dobrze? Skad bierze się szczęście? [...] Ty i ja, zupetnie obcy sobie ludzie. Różne gatunki zwierząt [Worożbyt 2017: 2]. Gdy odwiedziła monaster Wydubicki i stała przed ikoną św. Marii, miała mieszanie uczucia: z jednej strony opłakiwała wszystkich zabitych i modliła się o pokój w Ukrainie, z drugiej zaś pragnęła kochać się z Siergiejem.

Wyprawa do ATO była dla Nataszy czymś więcej niż zwykłą podróżą służbową. Chociaż starała się jak najwięcej się dowiedzieć o codziennym życiu wojennym i zapisać rozmowy z wyjątkowymi osobami, które wykazały się odwagą i nietuzinkowym zachowaniem $w$ trudnych sytuacjach, to jednak od samego początku pragnęła, aby nadarzyła się możliwość intymnego zbliżenia się z ukochanym. Póki jednak to nie nastąpiło, cierpliwie czekała. Uważnie obserwowała Siergieja w różnych sytuacjach (jak je, porusza się, stoi, śpi), zachwycała się, jak rozmawia z oficerami i żołnierzami, jak gra na gitarze: Ja i oficerowie patrzymy na ciebie $z$ uwielbieniem i podśpiewujemy nierównymi głosami. Jeden z oficerów filmuje ciebie i wrzuca wideo na fejsa. Sto, dwieście, tysiąc lajków! Nasze kobiety ostatnimi czasy wariuja na punkcie żotnierzy. Jedna moja znajoma zrobiła sobie nawet dziare „Za desantowców”. Teraz ja téz zwariowałam [Worożbyt 2017: 4].

Gdy widziała jego „silne i proste” plecy, jej oczy wypełniały się łzami. Były również jednak chwile, gdy uświadamiała sobie jego „,samotność i zdziczenie”.

Podróżując przez tereny wojenne, Natasza widziała ogromne zniszczenia. Przypomniało się jej, że jeden z jej przyjaciół z dzieciństwa zginął. Wpłynęło to negatywnie na jej psychikę. Chwilami odczuwała własną samotność. Coraz częściej przypominała sobie relacje z matką oraz dzieciństwo. Oto jedna ze scen: Kiedyś poktóciłam się z mama. Ma głupi zwyczaj, by nie zdejmować butów przy wejściu, tylko przechodzi przez caly korytarz i zdejmuje je przy salonie. Strasznie się pokłócityśmy. Nakrzyczałyśmy na siebie. A po kilku minutach rozlegt się wy- 
buch. To byt pierwszy wybuch w naszym miasteczku. Bardzo mocny. Natychmiast zapomniałyśmy o naszej kłótni. Mama rzuciła się do mnie z krzykiem „, Córeczko! Córeczko!'. Usiadlyśmy w drzwiach — uczono nas, by tak właśnie robić w czasie bombardowania. Mama histeryzowała, ptakała i powtarzała: ,, Córeczko!”. Nigdy nie zapomnę tego ,córeczko”, nigdy wcześniej tak do mnie nie mówiła... [Worożbyt 2017: 4-5].

Drugie wspomnienie jest związane z okresem, gdy Natasza jako mała dziewczynka lubiła się bawić z chłopcami z sąsiednich domów w ślub. Zawsze występowała w roli panny młodej, a na głowę zakładała tiul. Marzenie o pięknym życiu małżeńskim towarzyszyło jej przez całe życie.

Jednak najwięcej cierpień sprawiała jej niemożność intymnego kontaktu z Siergiejem. Były sytuacje, kiedy oboje byli bardzo blisko siebie, jednak on nigdy nie odważył się zrobić pierwszego kroku. Oto jak ona opisuje noc w jednym z hoteli: Chrapiesz. Cała noc tkwie jak na rozpalonych weglach. [...] Leżę na rozpalonych weglach z jednego jedynego powodu. Pragne ciebie. Wyobrażam sobie, jakby to mogło być. Jak wstajesz i podchodzisz do mnie. Albo wyciagasz rękę w ciemności. Albo nie, mówisz władczym głosem: „Chodź tutaj”. I ja wskakuję do twojego ciemnego tóżka. Ale ty mnie nie wołasz. Leżysz na sasiednim tóżku niczym zwierzę obłożone bronia i chrapiesz [Worożbyt 2017: 3].

Do pierwszego pocałunku doszło na terenie bazy wojskowej mieszczącej się na brzegu Morza Azowskiego. Jak wspominała Natasza, jej szczęście nie miało granic: Całujesz mnie po raz pierwszy. Sam wiesz, jak i kiedy to zrobić. Ja o niczym nie decyduję. Nogi się pode mna uginają. Nie mogę stać. Takie uczucie, [...]jakby to właśnie byt kadr z filmu o miłości, na która się tyle napatrzytam, o której tyle nastuchałam i która tyle razy przeżywałam za kogoś innego, tylko nie za siebie. Witaj, milości. Na twoją cześć po tamtej stronie wybuchaja pociski. Na twoją cześć urwato komuś nogę [Worożbyt 2017: 5].

Pierwszy kontakt intymny miał miejsce dopiero po tygodniu, gdy udało się znaleźć pokój z kanapą, czystą pościelą i prysznicem. Skończyło się to jednak niepowodzeniem: Siergiej nie miał erekcji. Przez chwilę jej się wydawało, że jest w stanie pogodzić się z zaistniałą sytuacją: Myślałam o tym, że tak właśnie wyglada rzeczywistość, tak właśnie wyglada miłość. I że jestem gotowa znosić taka mitość, nawet jeśli ci już nigdy nie stanie... Po prostu będę ciebie wachać [Worożbyt 2017: 6].

Z powodu niemożności zaspokojenia potrzeb seksualnych oraz odczucia szczęścia z ukochanym człowiekiem Natasza zmienia stosunek do Siergieja. Zdejmuje z niego nimb bohatera i patrioty, czyni go zwyczajnym człowiekiem. Uświadamia sobie, że „po krótkiej chwili bycia jednością” trzeba się rozstać na zawsze (Ale wiem, że się wściekniesz i zerwiesz ze mna wszelkie relacje. Przecież i tak nie mamy przyszłości. Zamykam oczy i nie widzę żadnej przyszłości przed nami [Worożbyt 2017: 6]). Aby ułatwić sobie ten proces, zastanawia się nad tym, w jaki 
sposób wymazać Siergieja ze swojej pamięci. Wyobraża sobie, że on pojedzie do Równego i ułoży sobie życie z inną kobietą ${ }^{3}$, a ona — ze swoim chłopakiem. Potem rodzi się myśl o tym, że może zostanie ranny, wzięty do niewoli albo nawet zabity. Nie wyklucza także tego, że uczyni go martwym w swoim reportażu. Przecież powinnościa ukraińskiego patrioty jest stużenie narodowi Ukrainy oraz obrona integralności i suwerenności państwa. [...] W razie konieczności musi oddać życie za jedność Ukrainy [Worożbyt 2017: 7].

\section{Trauma i próba jej przezwyciężenia}

Trzydziestodziewięcioletnia Ludmiła i żołnierz Władimir otrzymali rozkaz przekazania ciała zabitego oficera jego rodzinie. Wiktor (Witia) był kochankiem Ludmiły, został zabity przez separatystów. Poznała się z nim w wieku dziewięciu lat, kiedy jako dzieci byli razem w szpitalu w Charkowie. Ponownie się spotkali przez przypadek, na froncie. Ludmiła porzuciła firmę turystyczną, skończyła kurs medyczny i pracowała jako pielęgniarka. Wiktor miał rodzinę, ale zgłosił się na ochotnika, cieszył się uznaniem innych. Byt dobrym dowódca. Wesołym, dzielnym. Zarażat optymizmem [Worożbyt 2017: 20] — mówi o nim kierowca.

Na wojnie Ludmiła i Wiktor spędzili ze sobą kilka szczęśliwych miesięcy. Mieliśmy z Witią dziwny seks, właściwie parodię seksu. To jemu nie stawat, to mnie bolało... Przykro, jeśli kochasz, chcesz i nie możesz... Za to eksperymentowaliśmy [Worożbyt 2017: 22] — wyznaje kobieta. Jak można się domyślać, za ten właśnie „eksperyment” kobieta namiętnie go kochała.

Śmierć bliskiej osoby stała się dla Ludmiły traumą. Separatyści nie poprzestali na zabiciu go — odcięli mu głowę, a do tego zabrali komórkę, w której zachowała się ich intymna korespondencja. Te kilkanaście godzin, które kobieta spędza w samochodzie z ciałem zamordowanego i z kierowcą, są dla niej próbą wyjścia ze stanu depresji, przezwyciężeniem traumy. W scenie tej można dostrzec trzy z czterech etapów: 2) negacja / wypieranie, 3) przeżycie tragedii na nowo i katharsis oraz 4) ozdrowienie. Pierwszy etap, przetrwanie, odbył się wcześniej, ale autorka nie podaje nam informacji o zachowaniu się bohaterki.

Okres „negacji” trwał kilka godzin. Czytelnik jeszcze nie wie, w jakim celu i dokąd jedzie dwójka bohaterów. Ludmiła robi wszystko, aby podczas tej podróży nie ujawnić swojej traumy. Usiłuje zachować spokój i wykazać się opanowaniem. Najpierw prosi o włączenie radia i słucha muzyki, od czasu do czasu nucąc różne melodie. Potem pyta kierowcę o jego przedwojenne życie, ale nie pozwala mu odpowiedzieć na pytanie. Sama zabiera głos i opowiada o własnym życiu, np.

\footnotetext{
${ }^{3}$ Bohaterka podkreśla, że tylko ona i Siergiej żyją prawdziwym życiem. Żona Siergieja ma bzika na punkcie różnych metod odchudzania, a narzeczony Nataszy jest wegetarianinem.
} 
o latach studiów w Charkowie, o reakcji córki po powrocie do domu z kilkumiesięcznej ewakuacji. Od czasu do czasu bierze łyk alkoholu z manierki. W pewnym momencie wyznaje: On [Wiktor] miat piękne ciało. Ale teraz mnie nie pociaga. Poza tym jest bez głowy. Ciało bez głowy w worku zupetnie mnie nie pociaga [Worożbyt 2017: 21]. Składa kierowcy seksualną propozycję. Gdy ten kategorycznie odmawia, próbuje go zmusić. Nie mogąc pogodzić się z odmową, oskarża go o homoseksualizm (A może wolisz chtopców? Po to do wojska poszedteś, by czas z chłopaczkami spędzać? [Worożbyt 2017: 22]).

Trzeci etap — przeżycie tragedii na nowo i katharsis — przypada akurat na chwilę, gdy silnik gaśnie i kierowca nie może uruchomić samochodu. Żadna próba nie przynosi pożądanego rezultatu. Oboje są skazani na spędzanie zimowej nocy w nieogrzewanym samochodzie. Tę sytuację Ludmiła odbiera jako pewny znak. Przypomina sobie piosenkę w wykonaniu rosyjskiej śpiewaczki Tatiany Bułanowej: Nie płacz, została nam jeszcze jedna noc. Jeszcze jeden raz cicho ci powiem: „Jesteś mój!” [Worożbyt 2017: 22]. Przypomina sobie ciało kochanka (,był dobrze zbudowany, [...] nie musiał nawet specjalnie pakować"), chwile spędzone razem (,gdy jechał, lubił się rozpędzać”). Próbując nawiązać kontakt z Wiktorem, kilkakrotnie zwraca się do niego: „Witia, gdzieś ty głowę zgubił?!”, „Witia, pamiętasz nasze zabawy?". W pewnym momencie nawet mu się skarży na Władimira i prosi go o obronę: Witia, on mnie obraża. Witia, on mnie obraża. Zrób coś, Witia [Worożbyt 2017: 23].

Stan kobiety pogarsza się po otrzymaniu SMS-a o następującej treści: Luda, znajdź moją głowę. Wróć po moją głowę [Worożbyt 2017: 23]. Uświadamia sobie, że w taki sposób bawią się separatyści, którzy przywłaszczyli sobie telefon Wiktora. Zachowała się w nim ich korespondencja oraz zdjęcia. W pewnym momencie Ludmiła wpada na pomysł pozbycia się ciała kochanka, wymazania go z pamięci. Proponuje kierowcy, aby rozpalili ognisko i skremowali Wiktora, a popiół rozsypali („Pięknie będzie, symbolicznie”). Gdy próbuje wyciągnąć worek z martwym ciałem z samochodu, kierowca sprzeciwia się. Worek się rwie, a kobieta histeryzuje: On jest mój, co chcę, to i robię [Worożbyt 2017: 24]. Kierowcy nie pozostaje nic innego, jak tylko nie wpuścić jej do środka samochodu. Ludmiła krzyczy, thucze w szybę, a potem rzuca w szybę kamieniem. Następnie idzie do lasu i znika. Po pewnym czasie powraca i żali się, że zgubiła wisiorek sprezentowany przez Wiktora. Kierowca zmienia taktykę w stosunku do Ludmiły: uspokaja ją i pomaga przezwyciężyć ból.

Czwarty etap, „ozdrowienia”, ma miejsce następnego dnia. Gdy kierowca się budzi, widzi, że jego towarzyszka podróży jest opanowana, umyta i umalowana. Spotkała nawet osoby, które pomogą im uruchomić samochód. Podczas dalszej podróży Luda opowiada o tym, że śniły się jej buty — eskimoski z kryształkami, które kiedyś zobaczyła w Kijowie u jednej dziewczyny. Od tego czasu zapragnęła je mieć i teraz marzenie się spełniło. Na razie tylko we śnie. Był to kolejny znak, 
który ona odebrała jako konieczność rozstania się z Wiktorem. Poinformowała Władimira, że w najbliższej miejscowości wysiądzie i wróci innym samochodem. Natomiast on ma przekazać ciało jego żonie w wyznaczonym miejscu. Widząc zmianę stosunku Ludmiły do Wiktora, kierowca pozawala sobie na powiedzenie prawdy o oficerze: Czterech chlopaków wzią ze soba do grobu... Wszyscy wiedzieli, że to kretyńska akcja. [...] Ten twój Witia to drań [Worożbyt 2017: 25]. Jak w poprzednio opisanej scenie, jesteśmy świadkami deheroizacji bohatera.

\section{Przemoc i jej konsekwencje}

W czasie wojny agresja i przemoc są czymś naturalnym [Moskwin 2018: 83-98]. W świadomości człowieka zmuszonego do trzymania w rękach broni i zabijania wroga po pewnym czasie zachodzą procesy, które wpływają na jego zachowanie także w życiu codziennym. Jak stwierdza badacz Adam Frączek, należy zawsze brać pod uwagę zarówno motywy jednostki, jak i okoliczności i warunki, w których takie zachowanie występuje [Frączek 1993: 51]. Natalia Worożbyt dobitnie to pokazała w piątej scenie dramatu.

Dwudziestosześcioletnia dziennikarka z Kijowa — Julia — wyjechała do ATO, gdzie miała przeprowadzić wywiady z separatystami. Zaprzyjaźniła się z jednym z nich — Stasem. Jego rodzice, jak sam opowiada, żyją: matka pracuje, a ojciec jest alkoholikiem. Po ukończeniu studiów wyższych Stas pracował w budownictwie: Wogóle nie zamierzatem wojować. Chciatem budować dom. [...] Najbardziej, kurwa, pokojowy biznes. Jakie ja pałace ludziom stawiatem! [Worożbyt 2017: 29]. Po wydarzeniach na Majdanie poszedł do wojska, aby obronić Doniecką Republikę Ludową. Zabił około trzydziestu osób i w rezultacie trafił na listę Interpolu. Ma świadomość tego, że do końca życia nie będzie miał możliwości opuszczenia terenu Donbasu. Jest skazany na to, aby walczyć i zabijać. Oto jak opisuje swoje wrażenia z wojny: Pierwszego trupa się nie zapomina. A z dziesiątego można już obrączkę zdjać. Ja tego nie robiłem. Ale nie szokuje cię to. Cieszysz się, że to nie ty. A potem juz się nawet nie cieszysz, bo nic nie czujesz. Dno jest straszniejsze niż śmierć. Sięgnąeś dna i myślisz, że to dno... A tu chuj, pod nim jest kolejne dno... A pod nim jeszcze jedno... A pod nim martwy kolega z wyłupionymi oczami... Kto mu wytupit oczy? No przecież inny człowiek... A ty potem idziesz spokojnie żreć konserwę. Żresz i myślisz — następnemu jeńcowi też wytupię oczy. Na żywca. Mniam. [...] I nie ma drogi powrotnej [Worożbyt 2017: 32].

Opisany przez niego obraz świata przypomina ten stworzony przez radykalną prawicę: we wszystkich tragediach i kataklizmach świata winni są Żydzi, Amerykanie, homoseksualiści albo nacjonaliści: Tak. To, że brat na brata poszedt i krew przelewa, to ich robota. Caty wasz Majdan [Worożbyt 2017: 30]. Jest przekonany, że świat jest podzielony na dwie nierówne części: Tu nie chodzi o seks, tylko 
o władzę, o dominację nad światem. Pod pięknymi hastami «wartości europejskich» rozpętuja wojny, kłóca bratnie narody, by ostabić wplyw tych, którzy bronia prawdziwych wartości, takich jak rodzina, wiara, równość społeczna... [Worożbyt 2017: 30].

Julia, skromna, szczupła dziewczyna, stała się dla Stasa akurat jednym z tych wrogów. Jestem twoim wrogiem, ty, kurwa, przyjechałaś materialik o nas robić, ty chcesz nas zetrzeć z powierzchni ziemi [Worożbyt 2017: 30] — mówi jej w pewnym momencie. Zaprowadził ją do piwnicy dawnego budynku sanatorium, gdzie miał zamiar najpierw ją zgwałcić, a potem upokorzyć. Zdaje sobie sprawę, że jest silniejszy, ma nad nią ogromną przewagę i siłę. Może bezkarnie wyładować na niej swój gniew i urazę do świata. Używa różnych taktyk w stosunku do dziewczyny, przede wszystkim przemocy fizycznej i słownej (np. krzyki, groźby, przekleństwa).

Swoje spotkanie z Julią Stas zaczyna od tego, że uderza ją trzykrotnie w twarz, a następnie rozkazuje, aby się rozebrała. Straszy, że może ją zabić (przystawia nóż do gardła) albo że wydłubie jej oko. Od czasu do czasu powtarza: Jestem zwierzęciem, Jestem popieprzony na maksa. Lubię męczyć, jestem sadysta!, Jestem kompletnie porąbany [Worożbyt 2017: 26,33]. Stwierdza, że jest podniecony, kiedy ona się sprzeciwia i płacze. Okazuje się jednak, że mimo młodego wieku cierpi na zaburzenia erekcji. Z tego powodu złości się jeszcze bardziej. Straszy ją, że ponieważ sam nie może, to zawoła dziesięciu swoich kolegów, którzy ją zgwałcą: Porwa cię tu na wasza flagę, kurwa... Matka cię po majtkach nie pozna... [Worożbyt 2017: 27], Oni cię na śmierć zajebią. Czekaj, szykuj się. Albo się tbem o wannę zattucz. Zaraz po kolei tu przychodzić zaczna [Worożbyt 2017: 27]. Będąc w rozpaczy, rzuca się na nią i sam próbuje to zrobić, jednak nie potrafi. Drażni ją: Myślisz, że napiszesz potem na fejsie, jak dostałaś się do niewoli i Feliksa $a^{4}$ przerobilaś? Nie ciesz się. Ciebie stąd nogami do przodu wyniosa. I na twojej ściance napiszą: „Boże, jakie nieszczęście”, „taka młoda”, ,jaka straszna śmierć”... I jeszcze napisza — sama sobie winna, po cholerę tam polazła [Worożbyt 2017: 27].

Stas stosuje inne metody: sika na dziewczynę, szczypie za sutki. Jednak nie jest w stanie się podniecić. Próbuje się usprawiedliwić, zrzucić winę na dziewczynę: Gębę masz normalna. I figurę niezła. Ale seksu zero. [...] Kto chciatby cię przelecieć? [Worożbyt 2017: 29], Ale takie cycki mi się nie podobaja. Za blade [Worożbyt 2017: 31].

Julia ma świadomość tego, że kontakt ze Stasem może być dla niej niebezpieczny. Jest przestraszona, płacze, w pewnym momencie nawet traci przytomność. Powoli jednak usiłuje się opanować i zaczyna rozmawiać ze swoim katem: prosi go o przeniesienie spotkania na następny dzień; opowiada o wyjazdach z babcią do kurortu w Mirhorodzie; zadaje pytania dotyczące jego życia. Zachowuje się jak

4 Nawiązanie do Feliksa Dzierżyńskiego (1877-1926) — działacza rosyjskiej partii komunistycznej. Twórca sowieckiego aparatu terroru zwany Żelaznym Feliksem, Krwawym Feliksem i Czerwonym Katem. 
psychoterapeutka: próbuje skłonić go do pozytywnego myślenia, podbudować go. Dąży do tego, aby dostrzegł w swoim życiu dobre strony. Mówi do niego: Jesteś jedyny na świecie. Niepowtarzalny; Jesteś w moim typie [Worożbyt 2017: 29]. Nawet kiedy mężczyzna bije, powtarza: Ty jesteś dobry... Ja ciebie kocham ... Ja ciebie kocham ... [Worożbyt 2017: 27].

W rezultacie takie zachowanie przynosi pozytywny skutek. Stas się uspakaja, ma w oczach łzy, kiedy przypomina sobie babcię, potrafi cieszyć się z dźwięku świerszczy. Wydaje się, że wkrótce nastąpi happy end. Mówi do dziewczyny, aby jak najszybciej stąd uciekała: Spieprzaj stąd, póki jestem dobry [Worożbyt 2017: 33]. Jednak chęć uczynienia z Julii prostytutki zwycięża. Każe jej się rozebrać, przynosi wodę i pomaga się umyć. Gdy Julia zakłada mundur, dumnie stwierdza: Tracisz ludzki wygląd [Worożbyt 2017: 32]. Scena ta przypomina inicjację seksualną.

W finale Julia odnajduje w sobie siły, aby przeciwstawić się swojemu katowi. Korzystając z tego, że Stas złagodniał i na jakiś czas stracił kontrolę nad sytuacją, bierze cegłę i uderza go kilkakrotnie w głowę. W ten sposób odzyskuje wolność.

Innym wartym uwagi przykładem przejawu agresji jest druga scena dramatu. Dyrektor szkoły w trakcie przekroczenia punktu kontrolnego odkrywa, że zamiast swojego dowodu tożsamości ma inny — małżonki. Później jednak odnajduje własny (wypadł mu w samochodzie), ale te kilkanaście chwil, które spędził z żołnierzami armii ukraińskiej, zapamięta na całe życie. Został oskarżony przede wszystkim o nielegalne przekroczenie granicy, a ponadto zarzucono mu, że jest „narąbany”, a w bagażniku próbuje przewieźć kałasznikowa. Chociaż dyrektor stwierdza, że karabin jest tylko zwykłą atrapą, która zostanie wykorzystana na zajęciach z wychowania wojskowego, a kieliszek wódki musiał wypić w towarzystwie stacjonującego w mieście oddziału z okazji świętowania zwycięstwa jego szkoły w zawodach, w żaden sposób te argumenty nie zmieniły jego położenia. Dowódca próbował go zastraszyć, że wezwie odpowiednią jednostką i przesłucha go, a na razie wsadzi do ziemianki ze szczurami. Gdy sprawa została wyjaśniona, dość ostro powiedział: [...] ja walczę o to, by moja córka nie obudziła się któregoś dnia pośrodku wojny, jak wasze dzieci. I by się po piwnicach nie chowata. [...] I jeszcze stoję tu po to, by narąbany dyrektor szkoły nie wozit kałaszy w bagażniku... I żeby w ogóle takich dyrektorów na odległość wystrzatu z armaty nie dopuszczać do dzieci. Cholera wie, czego ty ich uczysz, jaka ojczyznę mają kochać. Z jaka ty byś flaga jeździt... [Worożbyt 2017: 15] .

Scena ta wyraźnie pokazuje, jak zwykły człowiek, który przez wiele lat spokojnie żył na tej ziemi, pracował, rzetelnie wykonywał swoje służbowe obowiązki, może zostać upokorzony przez wojsko swojego państwa.

Podsumowując, należy pokreślić, że w wykorzystanym do analizy dramacie świetnie widać to, co czyni z człowiekiem wojna, jak zniekształca jego psychikę

${ }^{5}$ Wszystkie podane w tekście cytaty zostały przetłumaczone przez autora artykułu. 
i świadomość, jak niszczy relacje międzyludzkie. Zle drogi to protest, bunt przeciwko katastrofie, a jednocześnie hymn miłości - zwykłej, ale czasem brutalnej, połączonej z koszmarem wojny.

\section{Wykaz wykorzystanej literatury}

Коженьовська-Бігун А., Образ війни на сході України у фейлетонах Наталії Ворожбит для польського журналу „Театр”, [в:] „Науковий вісник Чернівецького університетую Слов'янська філологія", 2018, № 798, с. 42-49.

Лабіринт із криги та вогню. Антологія актуальної драми. Революиія гідності й гібридна війна, ред. Н. Неждана, Київ: Смолоскип, 2019.

Майдан. До і після. Антологія актуальної драми, ред. Н. Неждана, О. МиколайчукНизовець, Київ: Світ знань, 2015.

Фанайлова Е., Ворожбит Н., „Не представляю себя пишущей без Украины” (30.04.2020), [в:] Електронний pecypc: https://www.svoboda.org/a/29444044.html (21.08.2020).

Herman J., Trauma and Recovery: the Aftermath of Violence — from Domestic Abuse to Political Terror, New York: BasicBooks 1992.

Moskwin A., Agresja i przemoc: przyczynek do problematyki, [w:] Wspótczesny dramat i teatr wobec wojny, przemocy i uchodźstwa, t. 2, red. A. Moskwin. Warszawa: KSI EŚW WLS UW, 2018, s. 83-98.

Nowy dramat ukraiński. W oczekiwaniu na Majdan, t. 1, red. A. Moskwin, A. Korzeniowska-Bihun, Warszawa: KSI EŚW WLS UW, 2015.

Socjalizacja i agresja, red. A. Frączek, H. Zumkley, Warszawa: Instytut Psychologii PAN, 1993.

\section{Wykaz wykorzystanych źródel}

Worożbyt N., Złe drogi (2017, tekst w języku rosyjskim), Archiwum Pracowni Badań nad Teatrem i Dramatem Europy Środkowo-Wschodniej WLS UW, fond 6, teczka 1, s. 1-37.

\section{Wykaz wykorzystanej literatury [References]}

Kozhenovska-Bihun A., Obraz viiny na skhodi Ukrainy u feiletonakh Natalii Vorozhbyt dlia polskoho zhurnalu ,Teatr" [The Image of War in the East of Ukraine Presented in Nataliya Vorozhbyt's Satirical Articles for the Polish Theatre Journal], [v:] „Naukovyi visnyk Chernivetskoho universytetu. Slovianska filolohiia”, 2018, № 798, s. 42-49.

Labirynt iz kryhy ta vohniu. Antolohiia aktualnoi dramy. Revoliutsiia hidnosti y hibrydna viina [Labyrinth from Ice and Fire. Anthology of New Drama. The Dignity Revolution and the Hybrid War], red. N. Nezhdana, Kyiv: Smoloskyp, 2019. 
Maidan. Do i pislia. Antolohiia aktualnoi dramy [Maidan. Before and After. Anthology of New Drama], red. N. Nezhdana, O. Mykolaichuk-Nyzovets, Kyiv: Svit znan, 2015.

Fanaylova Ye., Vorozhbit N., „Ne predstavlyayu sebya pishushchey bez Ukrainy” [„I can't imagine myself writing without Ukraine"] (30.04.2020), [v:] Elektronnyi resurs: https:// www.svoboda.org/a/29444044.html (21.08.2020).

Herman J., Trauma and Recovery: the Aftermath of Violence - from Domestic Abuse to Political Terror, New York: BasicBooks, 1992.

Moskwin A., Agresja i przemoc: przyczynek do problematyki [Aggression and Violence: Introduction to the Problem], [w:] Współczesny dramat i teatr wobec wojny, przemocy i uchodźstwa [Contemporary Drama and Theater in the Face of War, Violence and Refugee], t. 2, red. A. Moskwin. Warszawa: KSI EŚW WLS UW, 2018, s. 83-98.

Nowy dramat ukraiński. W oczekiwaniu na Majdan [New Ukrainian Drama. Waiting for the Maidan], t. 1, red. A. Moskwin, A. Korzeniowska-Bihun, Warszawa: KSI EŚW WLS UW, 2015.

Socjalizacja i agresja [Socialization and Aggression], red. A. Frączek, H. Zumkley, Warszawa: Instytut Psychologii PAN, 1993.

\section{Wykaz wykorzystanych źródel \\ [References]}

Worożbyt N., Złe drogi [Bad Roads] (2017, text in Russian), Archives of the Laboratory of Central and Eastern European Theater and Drama Research, fond 6, folder 1, p. 1-37. 